\title{
PEMBUATAN APLIKASI TOEFL SEBAGAI MEDIA PELATIHAN BAHASA INGGRIS BERBASIS WEB
}

\author{
Yongki Yonatan Marbun ${ }^{1)}$, R. Rizal Isnanto ${ }^{2)}$, Kurniawan Teguh Martono ${ }^{2)}$ \\ Program Studi Sistem Komputer, Fakultas Teknik, Universitas Diponegoro \\ Jalan Prof. Sudharto, Tembalang, Semarang, Indonesia
}

\begin{abstract}
Abstrak - Penggunaan internet telah memberikan kemudahan bagi pengguna dalam mengakses informasi. Salah satu layanan yang dari teknologi internet adalah web. Web selain berfungsi sebagai media informasi, juga dapat dijadikan sebagai media pelatihan dan pembelajaran. Salah satu contohnya yaitu penggunaan web dalam proses pelatihan dan pembelajaran TOEFL (Test of English as Foreign Language). TOEFL merupakan sebuah tes yang digunakan untuk mengukur kemampuan bahasa Inggris seseorang. Sementara itu untuk mendapatkan skor TOEFL yang tinggi bukanlah hal yang mudah. Biasanya peserta tes harus belajar dan mengerjakan soal TOEFL yang terdapat pada buku untuk mengukur kemampuannya. Metode belajar dengan menggunakan buku ini, membutuhkan waktu yang relatif banyak. Seseorang harus menjawab soal, kemudian memeriksa jawaban, menghitung jumlah soal yang benar, dan kemudian mengkonversi jumlah jawaban yang benar serta menghitung jumlah skor yang didapat. Dengan metode belajar yang seperti itu akan membutuhkan tambahan waktu.
\end{abstract}

Perancangan aplikasi TOEFL pada penelitian ini bertujuan untuk membuat aplikasi TOEFL yang dapat digunakan untuk menguji kemampuan diri dimana dalam pengaksesan aplikasi ini membutuhkan internet. Aplikasi ini berbasis web dengan menggunakan bahasa pemrograman PHP dan basisdata MySQL dengan menggunakan metode Waterfall pada proses perancangannya. Perencanaan sistem menggunakan metode terstruktur dengan mendefinisikan DFD, ERD, serta diagram alir sistem.

Pengujian aplikasi TOEFL ini menggunakan metode pengujian Black Box. Dimana berdasarkan pengujian black box yang sering disebut pengujian fungsionalitas semua tombol dapat digunakan dan menampilkan tanggapan sesuai keinginan dan pengujian oleh pengguna (Bheta testing) dengan hasil lebih besar dari $82 \%$, dan pengujian reliability menggunakan aplikasi WAPT 8.5 versi trial dengan $\mathbf{R}$ $=0.987$ dan error rate $=0.013 y$ ang berarti berdasarkan standar Telcordia perangkat ini memenuhi kriteria Reliability. Untuk selanjutnya, aplikasi ujian TOEFL berbasis web ini dapat dikembangkan dengan menggunakan bahasa pemrograman dan basisdata yang lain, dibuat dalam platform yang berbeda, serta dikembangkan dengan materi yang sesuai dengan kebutuhan dalam pengujian kemampuan bahasa Inggris seperti TOEF, TOEIC, dan IELTS.

Kata Kunci : Internet, TOEFL, Web, Black Box, Reliability

\section{Pendahuluan}

\subsection{Latar Belakang}

Seiring dengan perkembangan teknologi web yang sangat cepat, aplikasi-aplikasi web yang bermunculan juga semakin banyak. Meningkatnya teknologi web ini dipengaruhi juga karena kehadiran Internet. Kehadiran Internet dapat memudahkan kehidupan, salah satunya pada bidang pendidikan. Pada saat ini, sudah banyak situs web yang menyediakan media pembelajaran dan ujian online yang semakin interaktif serta mudah untuk dipelajari.

Pada zaman sekarang ini, bahasa Inggris merupakan salah satu bahasa internasional yang sering digunakan. Salah satu pelatihan bahasa Inggris yang sudah tidak asing lagi adalah TOEFL (Test of English as Foreign Language). Biasanya TOEFL digunakan untuk mempersiapkan diri bagi mereka yang ingin belajar ke luar negeri. Tetapi saat ini TOEFL juga digunakan oleh instansi pendidikan, seperti pada perkuliahan sebagai syarat masuk dan syarat kelulusan.

Untuk melatih kemampuan dalam menjawab soalsoal TOEFL tersebut, calon peserta membeli buku TOEFL dari toko buku untuk mendapatkan contoh soalsoal TOEFL yang biasanya digunakan pada ujian TOEFL. Metode belajar dengan menggunakan buku ini, membutuhkan waktu yang relatif banyak. Seseorang harus menjawab soal, kemudian memeriksa jawaban, menghitung jumlah soal yang benar, dan kemudian menghitung jumlah skor yang didapat. Dengan metode belajar yang seperti itu akan membutuhkan tambahan waktu.

Oleh karena itu, untuk memberikan alternatif dalam menguji kemampuan sebelum mengikuti ujian TOEFL PBT dibutuhkan suatu sarana bantuan yang harus bersifat hemat waktu (time saving), dan mempermudah dalam melakukan pengujian kemampuan diri. Permasalahan ini dapat diselesaikan dengan menggunakan fasilitas Internet yang dapat digunakan sebagai sarana untuk menguji kemampuan terhadap 
materi yang telah dipelajari yaitu berupa tes TOEFL untuk menguji kemampuan diri.

\subsection{Tujuan}

Tujuan dari Tugas Akhir ini adalah:

Membuat aplikasi ujian TOEFL sebagai media pelatihan berbasis web yang dapat digunakan untuk mengukur kemampuan diri.

\subsection{Batasan Masalah}

Dalam penulisan tugas akhir ini, penulis membatasi pembahasan dalam hal berikut:

1. Aplikasi Test TOEFL dirancang dan dibuat dengan menggunakan bahasa pemrograman PHP dan MySQL dimana aplikasinya berbasis web dan diakses berbasis desktop.

2. Tugas akhir ini terbatas hanya membahas cara perancangan dan pembuatan aplikasi ujian TOEFL.

3. Aplikasi ini hanya berupa aplikasi ujian TOEFL tanpa pembahasan dimana soal-soal yang disediakan diambil dari buku dan ujian dalam aplikasi ujian TOEFL ini meliputi: Reading, Grammar, dan Listening. Pada bagian Listening, aplikasi ini dilengkapi dengan dukungan pengaksesan audio (.wav atau .mp3).

4. Pengguna aplikasi ini adalah orang-orang yang ingin menguji kemampuan diri dalam bahasa Inggris.

5. Aplikasi yang dibuat merupakan aplikasi yang mirip dengan tes TOEFL PBT (Paper Based Test). Aplikasi ujian TOEFL ini hanya sebuah simulasi, yang digunakan untuk mengukur kemampuan diri pengguna bukan sebagai penilaian akhir hasil tes TOEFL dan tidak untuk menggantikan tes yang sebenarnya.

\section{LANDASAN TEORI}

\subsection{TOEFL}

TOEFL merupakan kependekan dari Test of English as a Foreign Language, yang merupakan ujian yang dilakukan untuk mengukur sejauh mana kemampuan bahasa Inggris seseorang. Tes ini digunakan untuk keperluan mendaftar ke lembaga pendidikan di Amerika Serikat maupun di negara lain. Tes ini pertama kali diadakan pada tahun 1963 dan telah diikuti oleh jutaan orang di seluruh dunia ${ }^{[3]}$. TOEFL PBT merupakan jenis tes TOEFL yang pertama kali digunakan. Dilakukan secara manual menggunakan kertas jawaban dimana peserta ujian harus menghitamkan pilihan jawaban dengan menggunakan pensil ${ }^{[4]}$.

TOEFL terdiri dari tiga bagian tes yang menjadi dasar, yaitu Listening Comprehension, Structure and Writtem Expression, dan Reading Comprehension.

Berikut ini adalah cara untuk menghitung skor TOEFL $^{[6]}$ :

1. Jumlahkan skor hasil konversi

Jumlah = skor listening + skor structure and written expression + skor reading

2. Bagi hasil penjumlahan diatas dengan 3
Jumlah = Jumlah : 3

3. Kalikan hasil pembagian dengan 10

Skor TOEFL $=$ hasil pembagian $* 10$

\subsection{Aplikasi Berbasis Web}

Salah satu keuntungan dari aplikasi berbasis web adalah kemudahan dalam mengakses data yang tidak terbatas tempat dan waktu, sedangkan kerugiannya adalah waktu yang diperlukan untuk menunggu saat sistem sedang memproses permintaan pengguna, sehingga waktu tunggu terhadap proses pada aplikasi berbasis web diperlukan waktu tunggu yang lebih lama. Hal ini berbeda dengan aplikasi berbasis desktop dimana aplikasi tersebut harus melakukan proses instalasi aplikasi terlebih dahulu di komputer yang akan digunakan untuk mengakses data, namun memiliki keunggulan dalam proses pelaksanaan instruksi, tanpa memerlukan waktu tunggu ke server ${ }^{[9]}$.

\subsection{PHP}

PHP adalah singkatan dari "PHP: Hypertext Prepocessor", yaitu bahasa pemrograman universal yang digunakan secara luas untuk penanganan pembuatan dan pengembangan sebuah situs web dan dapat digunakan bersamaan dengan HTML.

PHP Pertama kali ditemukan pada 1995 oleh seorang Software Developer bernama Rasmus Lerdrof. Ide awal PHP adalah ketika itu Radmus ingin mengetahui jumlah pengunjung yang membaca resume online-nya. Script yang dikembangkan baru dapat melakukan dua pekerjaan, yakni merekam informasi pengunjung, dan menampilkan jumlah pengunjung dari suatu website. Dan sampai sekarang kedua tugas tersebut masih tetap populer digunakan oleh dunia web saat ini. Kemudian, dari situ banyak orang di milis mendiskusikan script buatan Rasmus Lerdrof, hingga akhirnya Rasmus mulai membuat sebuah tool/script, bernama Personal Home Page (PHP) ${ }^{[13] .}$

\subsection{MySQL}

MySQL merupakan software yang tergolong sebagai DBMS (Database Management System) yang bersifat Open source. Open source menyatakan bahwa software ini dilengkapi dengan source code (kode yang dipakai untuk membuat MySQL), selain tentu saja bentuk executetable-nya atau kode yang dapat dijalankan secara langsung dalam sistem operasi, dan dapat diperoleh dengan cara men-download (mengunduh) di Internet secara gratis $^{[15]}$.

Basisdata adalah suatu tools yang digunakan untuk menyimpan informasi, mengambil informasi kapanpun dibutuhkan, dan mengatur informasi yang tersimpan. Jika digambarkan Lemari File merupakan suatu basisdata ${ }^{[17]}$. Basisdata merupakan suatu kumpulan data yang berhubungan secara logis dan deskripsi data tersebut, yang dirancang untuk memenuhi informasi yang dibutuhkan oleh suatu organisasi. Artinya, basisdata merupakan tempat penyimpanan data yang besar, dimana dapat digunakan oleh banyak pengguna.

\subsection{CSS}


CSS atau Cascading Style Sheet adalah bahasa pemrogramman yang digunakan untuk mendeskripsikan bagaimana suatu konten akan ditampilkan. Kita memberikan karakteristik tampilan dari elemen yang ada pada HTML menggunakan $\mathrm{CSS}^{[18]}$.

\subsection{Metode Waterfall}

Model pengembangan ini dimulai dari tahap awal pengembangan sistem yaitu tahap perencanaan sampai tahap akhir pengembangan sistem yaitu tahap pemeliharaan. Tahapan berikutnya tidak akan dilaksanakan sebelum tahapan sebelumnya selesai dilaksanakan dan tidak dapat kembali atau mengulang ke tahap sebelumnya ${ }^{[20]}$. Langkah-langkah pemodelan Waterfall dapat dilihat pada Gambar 1:

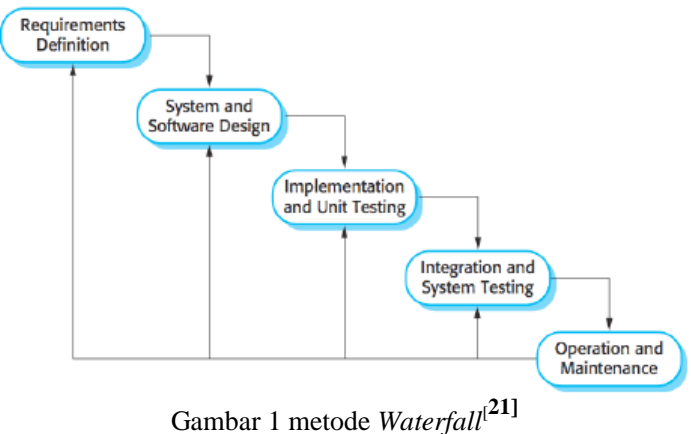

Tahapan pada pemodelan perangkat lunak menggunakan model waterfall terdiri atas defenisi kebutuhan, perancangan sistem dan perangkat lunak, Pengujian unit dan implementasi, pengujian sistem dan integrasi, dan penerapan program dan pemeliharaan ${ }^{[21]}$.

\subsection{Skala Likert}

Skala Likert adalah skala yang digunakan untuk mengukur sikap, pendapat, dan persepsi seseorang atau sekelompok orang tentang fenomena sosial ${ }^{[22]}$. Data yang telah terkumpul melalui angket, kemudian diolah ke dalam bentuk kuantitatif, yaitu dengan cara menetapkan skor jawaban dari pertanyaan yang telah dijawab responden.

Berdasarkan data hasil kuesioner, persentase masing-masing jawaban dapat dihitung dengan rumus ${ }^{[22]}$ :

Keterangan :

$$
Y=\frac{X}{i} \times 100 \%
$$

$$
\begin{aligned}
& Y \quad=\text { Nilai presentase } \\
& i \quad=\text { Skor ideal (skor tertinggi Likert dikali } \\
& \text { dengan jumlah responden) } \\
& X \quad=\text { Total skor }
\end{aligned}
$$

Berikut ini kriteria interpretasi skor untuk skala Likert:

$0 \% \leq \mathrm{Y} \leq 20 \%=$ Sangat Lemah

$21 \% \leq \mathrm{Y} \leq 40 \%=$ Lemah

$46 \% \leq \mathrm{Y} \leq 60 \%=$ Cukup

$61 \% \leq \mathrm{Y} \leq 80 \%=$ Kuat

$81 \% \leq \mathrm{Y} \leq 100 \%$ = Sangat Kuat

\subsection{Pengujian Reliability}

Pengujian reliability dapat dilakukan dengan mengukur frekuensi dan tingkat kegagalan, keakuratan hasil output, mean-time-to-failed (MTTF), kemampuan untuk pulih dari kegagalan dan prediktabilitas program ${ }^{\text {[23]. }}$ Analisis kualitas aspek reliability dilakukan dengan menggunakan rumus dari Nelson yaitu ${ }^{[24]:}$

$$
\mathrm{R}=1-\frac{f}{n}=1-\mathrm{r}
$$

Dimana:

$$
\begin{aligned}
& R=\text { reliability } \\
& f=\text { total failure } \\
& n=\text { total test case } \\
& r=\text { error rate }
\end{aligned}
$$

\section{Perancangan Sistem}

\subsection{Analisis Kebutuhan Sistem}

Untuk memahami sifat dan fungsi perangkat lunak yang akan dibangun, analisa harus memahami informasi dan juga tingkah laku yang harus dimiliki sistem. Pada analisa kebutuhan ini dilakukan pencarian terhadap kebutuhan-kebutuhan yang dibutuhkan dan harus dimiliki oleh sistem sehingga nanti pengerjaan aplikasi dapat memperoleh hasil yang diinginkan.

Identifikasi masukan merupakan tahapan untuk mengumpulkan informasi yang dibutuhkan oleh sistem aplikasi yang nantinya akan di proses oleh sistem. Data masukan ini diperloleh dari admin dan juga dari sisi penggguna. Dari sisi admin, data masukan adalah berupa pertanyaan dan jawaban yang nantinya akan diajukan sistem kepada pengguna, audio dan teks reading. Dari sisi pengguna, data masukan berupa identitas diri yang akan di inputkan pada saat pengguna ingin membuat akun agar pengguna bisa masuk ke dalam sistem. Selain itu, masukan dari sisi pengguna juga berupa jawaban dari pertanyaan-pertanyaan yang diajukan oleh sistem dan juga berupa pesan yang ingin disampaikan pengguna kepada admin.

Identikasi keluaran merupakan tahapan untuk menentukan tahapan hasil dalam bentuk skor TOEFL yang diperoleh dari jawaban-jawaban yang dimasukan oleh pengguna ke dalam sistem. Selain itu, keluaran dari sistem ini juga berupa pertanyaan-pertanyaan, keterangan soal, dan pilihan jawaban yang sudah diinputkan admin ke dalam sistem. Kemudian pengguna akan memberi respon dengan cara memasukkan jawaban yang dianggap paling benar terhadap soal-soal yang ditampilkan oleh sistem. Jawaban-jawaban kemudian akan diperiksa oleh sistem apakah benar atau salah berdasarkan jawaban yang benar yang telah diinputkan oleh admin. Jumlah benar dari jawaban benar yang dimasukkan oleh pengguna akan mempengaruhi jumlah skor TOEFL yang akan didapatkan pengguna. Semakin banyak jumlah jawaban yang benar, maka semakin tinggi pula skor TOEFL yang akan didapatkan oleh pengguna tersebut.

Berikut ini merupakan aktor yang berperan di dalam aplikasi TOEFL dan berikut deskripsi aktivitas yang dapat dilakukan oleh masing-masing aktor seperti ditunjukkan pada Tabel 1.

Tabel 1 Aktor yang terlibat 


\begin{tabular}{|l|l|l|}
\hline No & \multicolumn{1}{|c|}{ Aktor } & \multicolumn{1}{c|}{ Deskripsi } \\
\hline 1. & Pengguna (user) & $\begin{array}{l}\text { Pengguna dapat mendaftarkan diri } \\
\text { untuk membuat akun, dapat } \\
\text { melakukan log in untuk masuk ke } \\
\text { dalam sistem, dapat mengubah } \\
\text { password, menjawab soal-soal yang } \\
\text { disediakan sistem, melihat skor } \\
\text { TOEFL, dan memberikan pesan } \\
\text { kepada admin. }\end{array}$ \\
\hline 2. & Admin & $\begin{array}{l}\text { Admin memiliki hak akses tertinggi } \\
\text { untuk mengelola soal-soal yang } \\
\text { akan dibutuhkan sistem, mengelola } \\
\text { akun pengguna, melihat daftar user } \\
\text { dan skor TOEFL, dan mengelola } \\
\text { kotak pesan pengguna. }\end{array}$ \\
\hline
\end{tabular}

Langkah selanjutnya setelah menentukan kebutuhan sistem adalah membuat desain atau gambaran umum dari sistem dengan menggunakan metode terstruktur yaitu context diagram, data flow diagram serta penggambaran proses melalui diagram alir.

\subsection{Proses Desain Sistem}

Tahapan selanjutnya adalah proses desain sistem sebagai gambaran dasar bentuk sistem. Dalam melakukan desain sistem terdapat beberapa hal yang harus dibuat yaitu desain proses kerja, desain basis data dan desain tampilan sistem. Pemodelan desain proses kerja menggunakan metode terstruktur, yaitu context diagram dan DFD (data flow diagram) level 1.

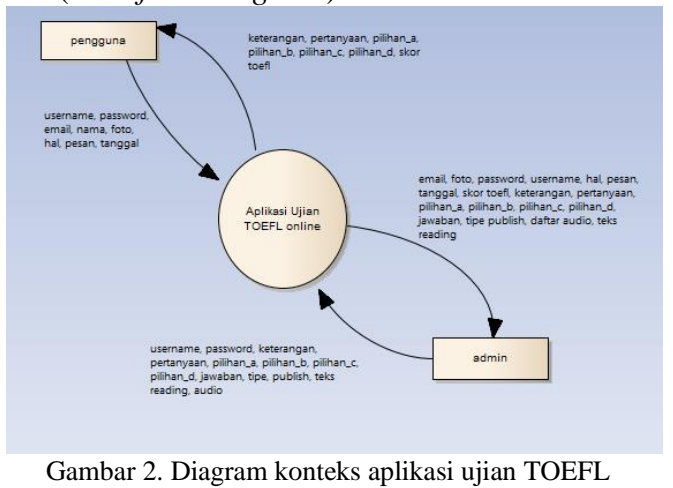

Gambar 2 merupakan gambaran umum tentang sistem meliputi entitas luar (pengguna, dan admin), proses (aplikasi ujian TOEFL), serta data apa saja yang mengalir pada sistem. Selain itu, pada sistem ini nantinya juga akan terdapat beberapa penyimpanan data (user, audio, kotak_pesan, soal_listening, soal_grammar, soal_grammar, teks_reading, tabel_nilai, dan tabel_konversi). Proses yang lebih rinci dari diagram konteks tersebut dapat dijabarkan lagi dalam bentuk Data Flow Diagram (DFD) level 0.

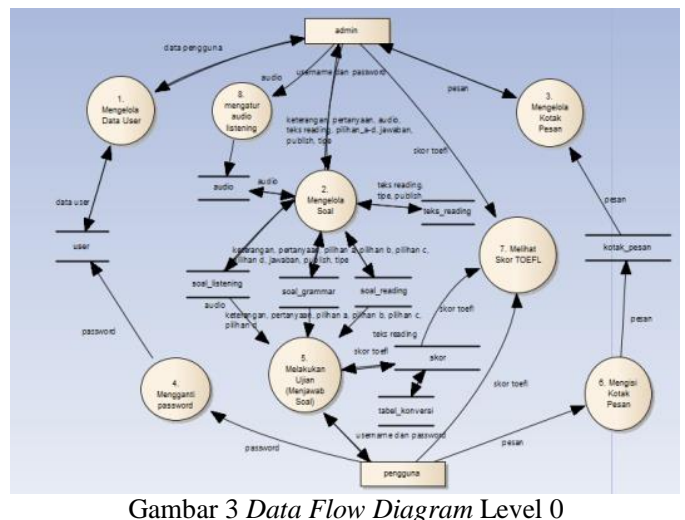

Gambar 3 menunjukkan DFD Level 0 yang menggambarkan proses apa saja yang terdapat dalam sistem pakar. Dalam gambar tersebut, terdapat delapan proses utama yang menghubungkan entitas maupun proses ke penyimpanan data. Delapan proses tersebut diantaranya adalah:

1. Proses 1 yaitu proses mengelola data pengguna. Pada proses DFD level 1.1 ini, proses mengelola data pengguna ini dapat dijelas lagi menjadi proses melihat data pengguna, dan menghapus data pengguna.

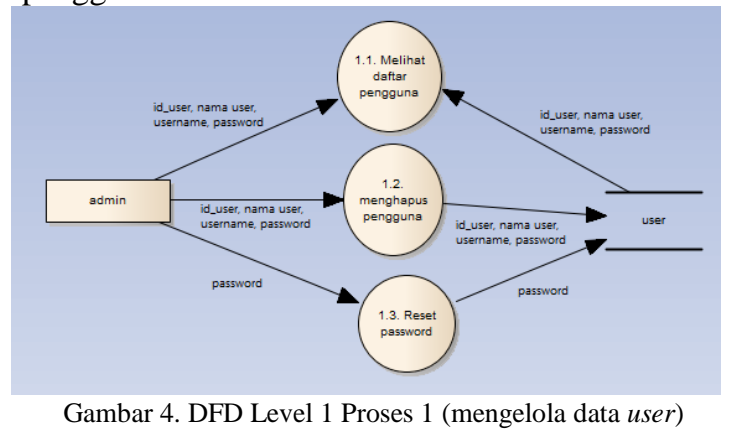

2. Proses 2 yaitu mengelola soal yang dibutuhkan untuk aplikasi ujian TOEFL, beberapa proses yang dapat dilakukan dalam mengelola soal diantaranya adalah menambah soal listening, melihat soal listening, mengubah soal listening, menghapus soal listening, menambah soal grammar, melihat soal grammar, mengubah soal grammar, menghapus soal grammar, menambah soal reading, melihat soal reading, mengubah soal reading, menghapus soal reading.

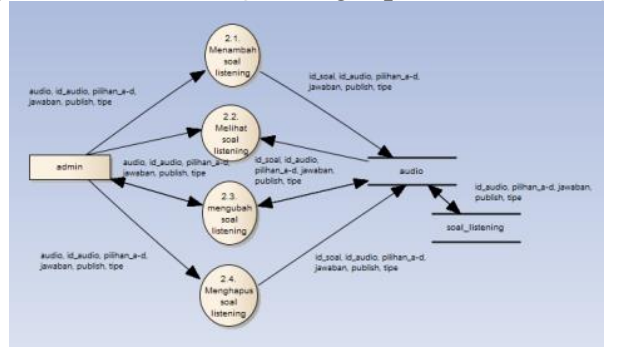




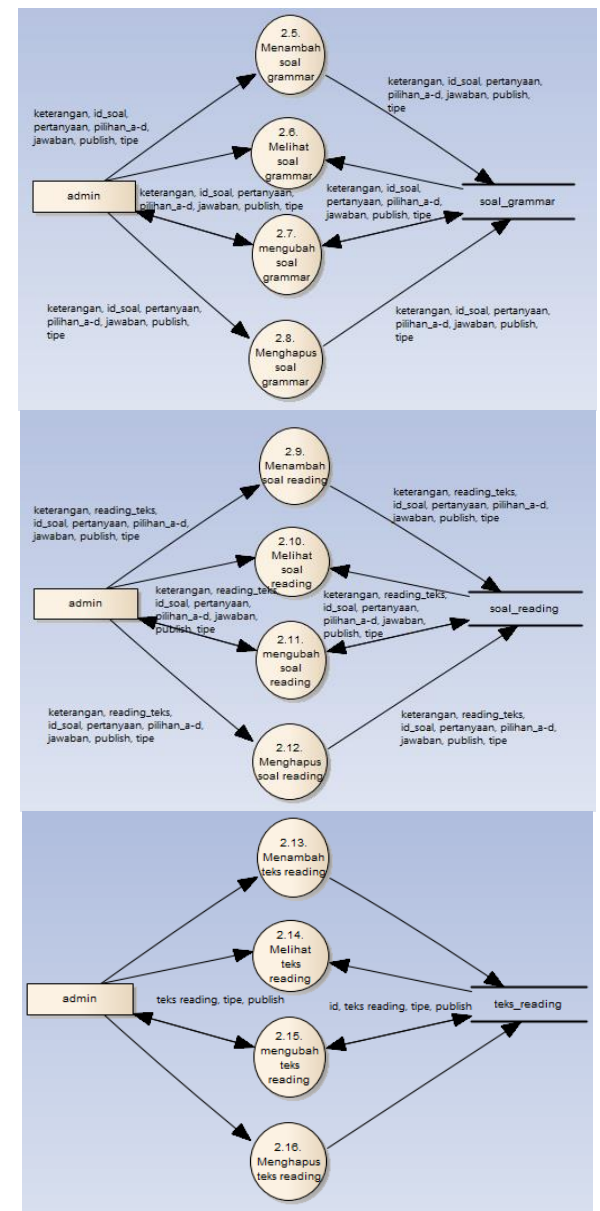

Gambar 5. DFD Level 1 Proses 2 (Mengelola Soal)

3. Proses 3 yaitu mengelola kotak pesan, beberapa proses yang dapat dilakukan dalam mengelola kotak pesan adalah melihat kotak pesan yang diisi oleh pengguna serta menghapus pesan.

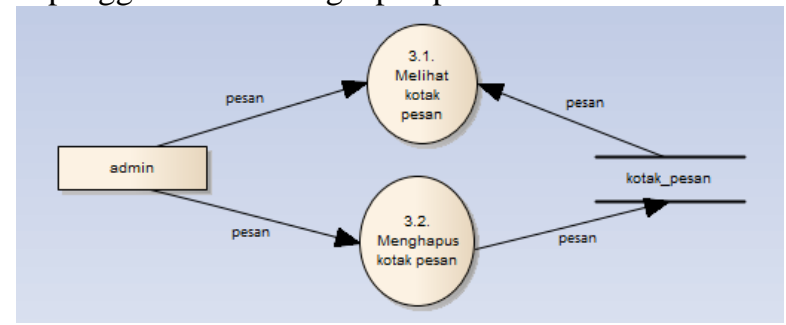

Gambar 6. DFD Level 1 Proses 3 (Mengelola kotak pesan)

Setelah melakukan perancangan alur kerja sistem, tahapan selanjutnya adalah melakukan perancangan basisdata. Dalam melakukan perancangan basisdata, beberapa tahapan yang dilakukan adalah menentukan entitas apa saja yang akan terlibat. Entitas yang terlibat dan dibuat sendiri dalam penelitian ini sebanyak sembilan buah, diantaranya: user, soal_listening, soal_grammar, soal_reading, tabel_nilai,_ kotak_pesan, audio, teks_reading, tabel_konversi. Setelah menentukan entitas apa saja yang terlibat, tahapan selanjutnya adalah menentukan atribut dari tiap entitas tersebut. Tabel 1hingga tabel 9 adalah perincian dari atribut pada tiap-tiap entitas. Basisdata yang digunakan pada sistem ini seperti ditunjukkan pada Tabel 2 - Tabel 10.

\begin{tabular}{|l|l|l|l|l|}
\hline No & Kolom & Tipe Data & Keterangan & Deskripsi \\
\hline 1. & id_user & INT(4) & Unique key & Kolom untuk ID user \\
\hline 2. & username & VARCHAR(50) & Primary Key & Kolom untuk username \\
\hline 3. & password & VARCHAR(32) & - & Kolom untuk password \\
\hline 4. & email & VARCHAR(50) & - & Kolom untuk email user \\
\hline 5. & gambar_user & VARCHAR(50) & - & Kolom untuk Gambar user \\
\hline 6. & level & VARCHAR(5) & - & Kolom untuk level \\
\hline
\end{tabular}

Tabel 3 Tabel soal_listening

\begin{tabular}{|l|l|l|l|l|}
\hline No & Kolom & Tipe Data & Keterangan & Deskripsi \\
\hline 1. & id soal & INT(4) & Primary Key & Kolom untuk ID soal \\
\hline 2. & id_audio & VARCHAR(100) & & Kolom untuk ID Audio \\
\hline 3. & keterangan & VARCHAR(10000) & - & Kolom untuk keterangan \\
\hline 4. & pilihan a & VARCHAR(500) & - & Kolom untuk pilihan A \\
\hline 5. & pilihan b & VARCHAR(500) & - & Kolom untuk pilihan B \\
\hline 6. & pilihan_c & VARCHAR(500) & - & Kolom untuk pilihan C \\
\hline 7. & pilihand & VARCHAR(500) & - & Kolom untuk pilihan D \\
\hline 8. & Jawaban & VARCHAR(100) & - & Kolom untuk jawaban \\
\hline 9. & publish & ENUM('yes','no') & - & Kolom untuk pilihan publish \\
\hline 10. & tipe & INT(2) & - & Kolom untuk tipe soal \\
\hline
\end{tabular}

Tabel 4 Tabel soal_grammar

\begin{tabular}{|l|l|l|l|l|}
\hline No & Kolom & Tipe Data & Keterangan & Deskripsi \\
\hline 1. & id_soal & INT(4) & Primary Key & Kolom untuk ID soal \\
\hline 2. & pertanyaan & VARCHAR(1000) & - & Kolom untuk pertanyaan \\
\hline 3. & pilihan_a & VARCHAR(500) & - & Kolom untuk pilihan A \\
\hline 4. & pilihan_b & VARCHAR(500) & - & Kolom untuk pilihan B \\
\hline 5. & pilihan_c & VARCHAR(500) & - & Kolom untuk pilihan C \\
\hline 6. & pilihan_d & VARCHAR(500) & - & Kolom untuk pilihan D \\
\hline 7. & Jawaban & VARCHAR(100) & - & Kolom untuk jawaban \\
\hline 8. & publish & ENUM('yes','no') & - & Kolom untuk pilihan publish \\
\hline 9. & tipe & INT(2) & - & Kolom untuk tipe soal \\
\hline
\end{tabular}

Tabel 5 Tabel soal_reading

\begin{tabular}{|l|l|l|l|l|}
\hline No & Kolom & Tipe Data & Keterangan & Deskripsi \\
\hline 1. & id_soal & INT(4) & Primary Key & Kolom untuk ID soal \\
\hline 2. & id reading & VARCHAR(6) & - & Kolom untuk ID reading \\
\hline 3. & pertanyaan & VARCHAR(1000) & - & Kolom untuk pertanyaan \\
\hline 4. & pilihan a & VARCHAR(500) & - & Kolom untuk pilihan A \\
\hline 5. & pilihan b & VARCHAR(500) & - & Kolom untuk pilihan B \\
\hline 6. & pilihan_c & VARCHAR(500) & - & Kolom untuk pilihan C \\
\hline 7. & pilihand & VARCHAR(500) & - & Kolom untuk pilihan D \\
\hline 8. & Jawaban & VARCHAR(100) & - & Kolom untuk jawaban \\
\hline 9. & publish & ENUM('yes','no') & - & Kolom untuk pilihan publish \\
\hline 10. & tipe & INT(2) & - & Kolom untuk tipe soal \\
\hline
\end{tabular}

Tabel 6 Tabel tabel_nilai

\begin{tabular}{|l|l|l|l|l|}
\hline No & Kolom & Tipe Data & Keterangan & Deskripsi \\
\hline 1. & id_nilai & INT(4) & Primary Key & Kolom untuk ID nilai \\
\hline 2. & id_user & INT(4) & - & Kolom untuk ID user \\
\hline 3. & nilai_listening & INT(4) & - & Kolom untuk nilai listening \\
\hline 4. & nilai_grammar & INT(4) & - & Kolom untuk nilai grammar \\
\hline 5. & nilai_reading & INT(4) & - & Kolom untuk nilai reading \\
\hline 6. & nilai_akhir & INT(4) & - & Kolom untuk nilai akhir \\
\hline 7. & tanggal & DATE & - & Kolom untuk tanggal \\
\hline
\end{tabular}

Tabel 7 Tabel kotak_pesan

\begin{tabular}{|l|l|l|l|l|}
\hline No & Kolom & Tipe Data & Keterangan & Deskripsi \\
\hline 1. & id pesan & INT(4) & Primary Key & Kolom untuk ID pesan \\
\hline 2. & hal & VARCHAR(1000) & - & Kolom untuk hal \\
\hline 3. & nama & VARCHAR(50) & - & Kolom untuk nama pemberi pesan \\
\hline 4. & email & VARCHAR(50) & - & Kolom untuk email \\
\hline 5. & pesan & VARCHAR(10000) & - & Kolom untuk pesan \\
\hline 6. & tanggal & DATE & - & Kolom untuk tanggal \\
\hline
\end{tabular}

Tabel 8 Tabel audio

\begin{tabular}{|l|l|l|l|l|}
\hline No & Kolom & Tipe Data & Keterangan & Deskripsi \\
\hline 1. & id_audio & INT(4) & Primary Key & Kolom untuk ID audio \\
\hline 2. & nama_cudio & VARCHAR(200) & - & Kolom untuk nama audio \\
\hline 3. & status & VARCHAR(10) & - & Kolom untuk status audio \\
\hline
\end{tabular}

Tabel 9 Tabel teks_reading 


\begin{tabular}{|l|l|l|l|l|}
\hline No & Kolom & Tipe Data & Keterangan & Deskripsi \\
\hline 1. & id reading & INT(4) & Primary Key & Kolom untuk ID reading \\
\hline 2. & reading teks & VARCHAR(10000) & - & Kolom untuk teks reading \\
\hline 3. & publish & ENUM('yes','no') & - & Kolom untuk publish \\
\hline 4. & tipe & INT(2) & - & Kolom untuk tanggal \\
\hline
\end{tabular}

Tabel 10 Tabel tabel_konversi

\begin{tabular}{|l|l|l|l|l|}
\hline No & Kolom & Tipe Data & Keterangan & Deskripsi \\
\hline 1. & id & INT(4) & Primary Key & Kolom untuk ID \\
\hline 2. & jumlah_benar & INT(4) & - & Kolom untuk jumlah benar \\
\hline 3. & konversi_listening & INT(4) & - & Kolom untuk konversi listening \\
\hline 4. & konversi_grammar & INT(4) & - & Kolom untuk konversi grammar \\
\hline 5. & konversi_reading & INT(4) & - & Kolom untuk konversi reading \\
\hline
\end{tabular}

Tahapan selanjutnya adalah melakukan perancangan diagram alir yang menggambarkan aliran proses yang terdapat didalam sistem. Gambaran tersebut digambarkan dalam diagram alir dari aplikasi TOEFL yang ditunjukkan pada Gambar 7 - Gambar 10 berikut.

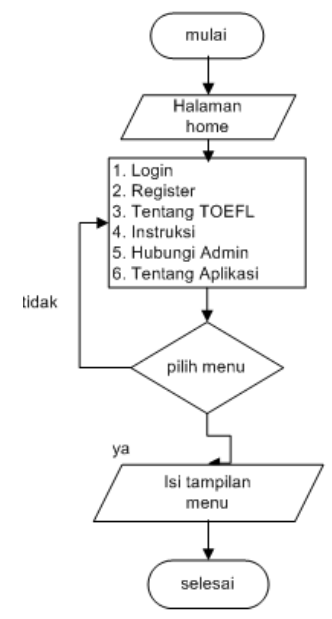

Gambar 7. Diagram Alir beranda sistem

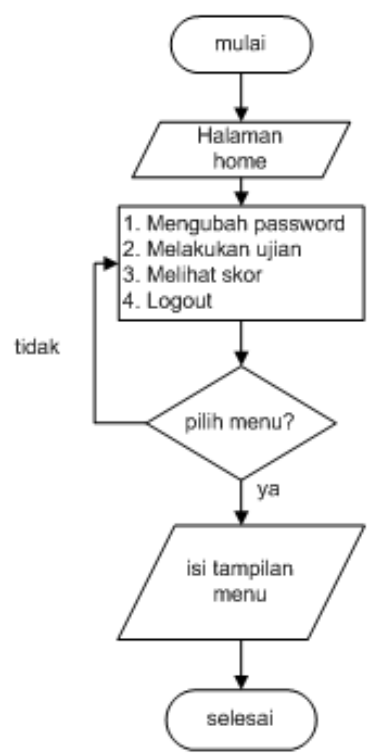

Gambar 8 Diagram Alir halaman user

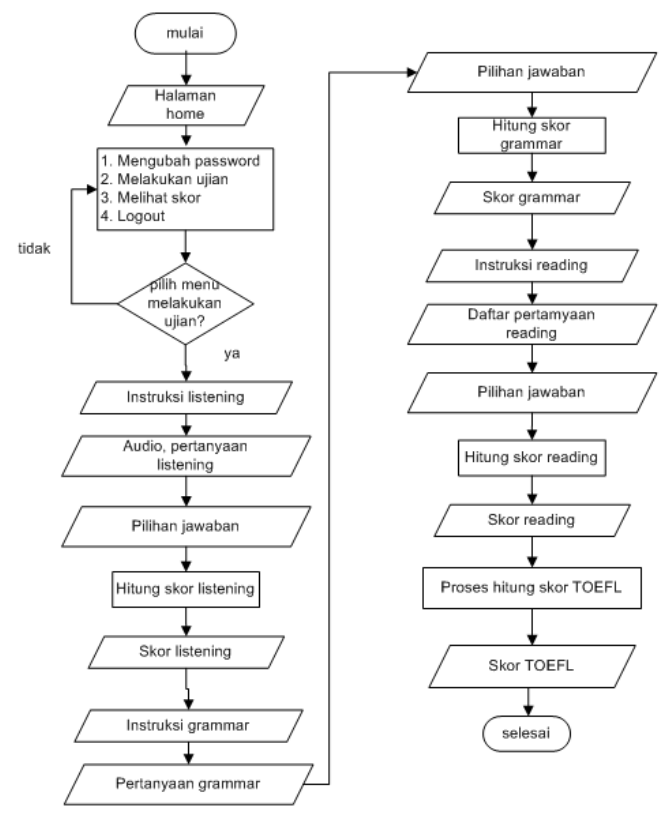

Gambar 9 Diagram Alir melakukan ujian

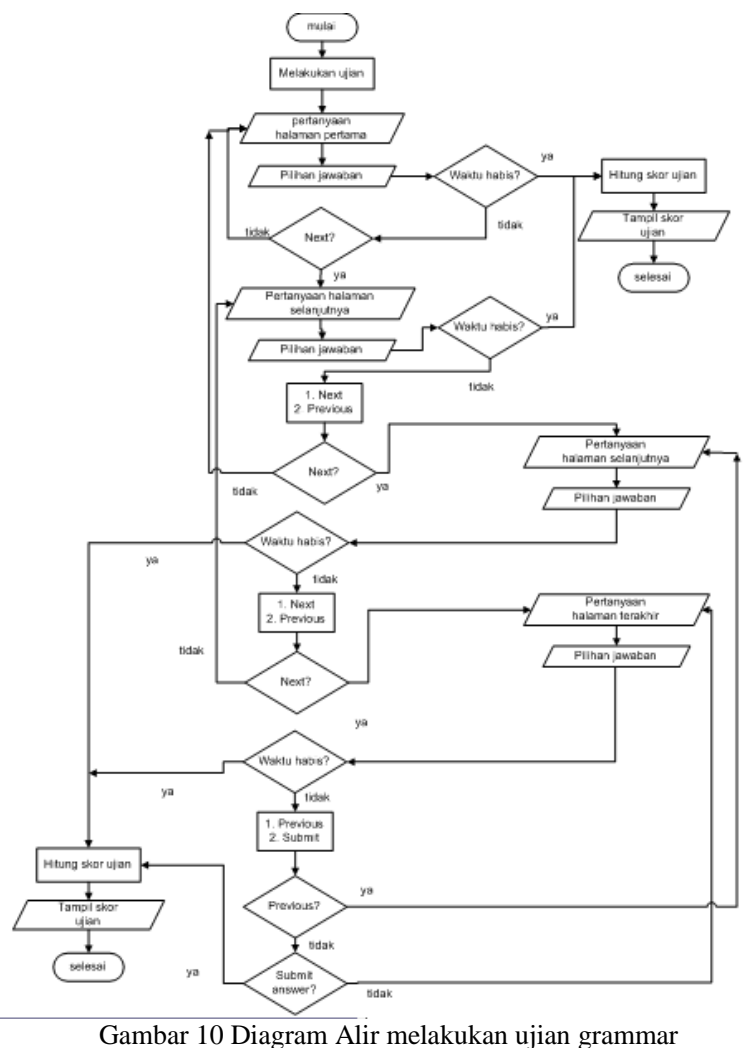

Perancangan atarmuka bertujuan untuk memberikan gambaran tentang aplikasi yang akan dibangun, sehingga dapat memberikan gambaran untuk calon pengguna aplikasi. Selain itu, dengan melakukan perancangan antarmuka diharapkan dapat mempermudah dalam melakukan implementasi serta memudahkan pengembang sistem dalam membangun aplikasi. Beberapa contoh tampilan antarmuka perancangan aplikasi TOEFL dapat ditunjukkan pada Gambar 11 - Gambar 14. 


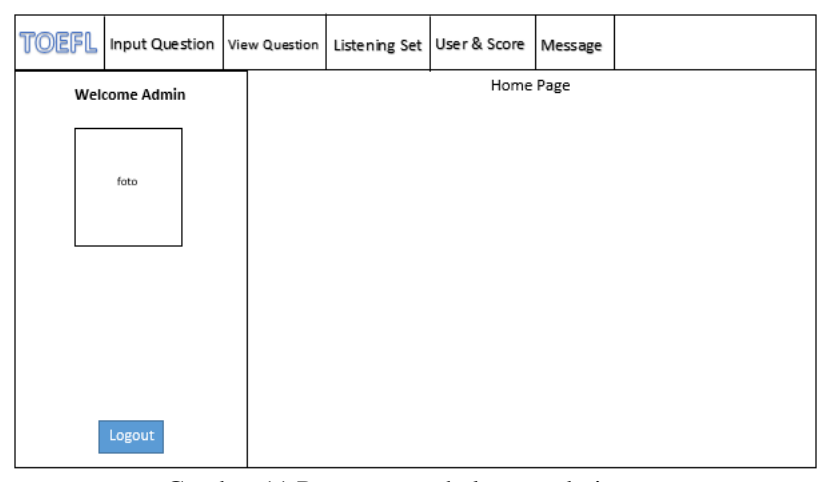

Gambar 11 Perancangan halaman admin

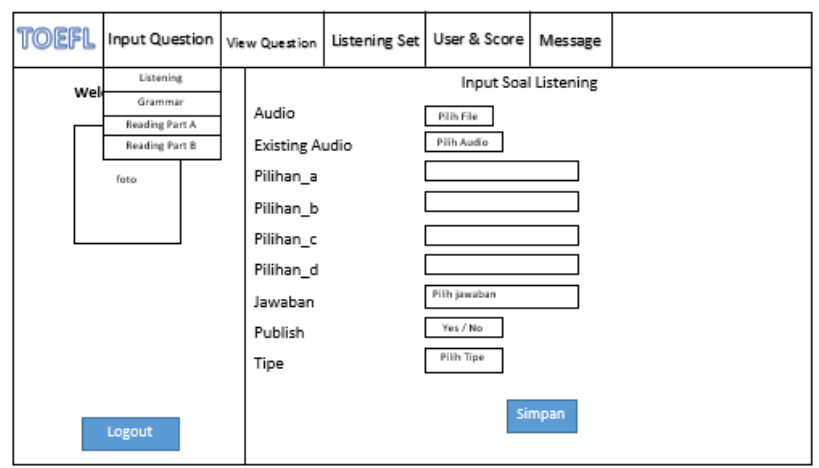

Gambar 12 Perancangan menambah pertanyaan

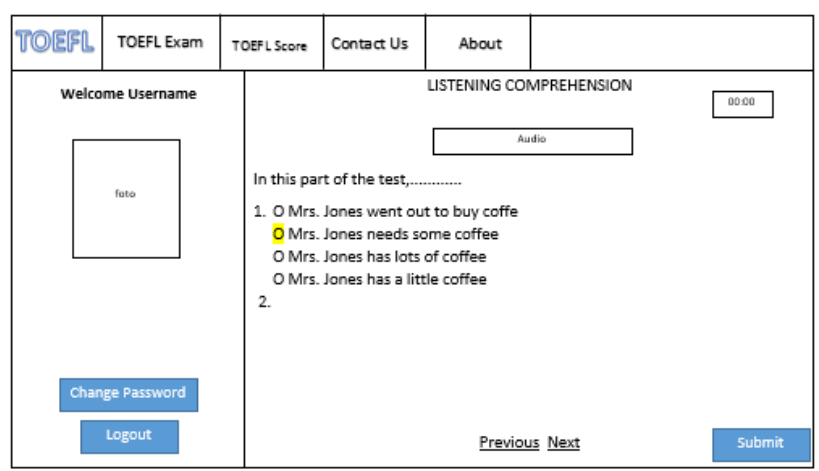

Gambar 13 Perancangan antarmuka user melakukan ujian

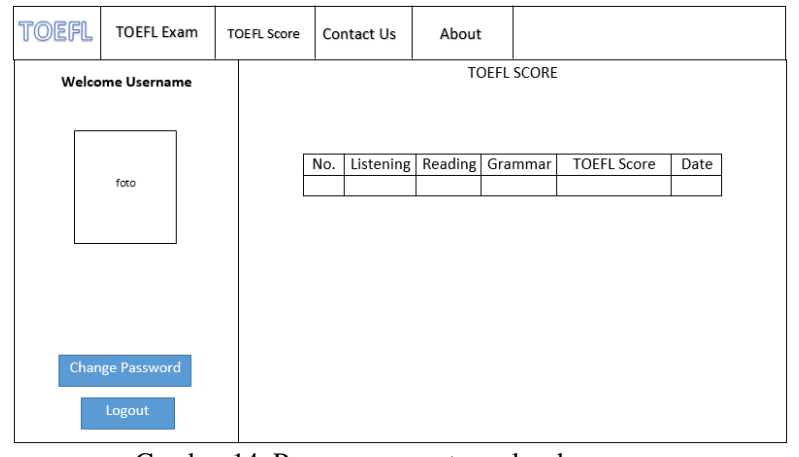

Gambar 14 Perancangan antarmuka skor $u$ ser

\section{IMPLEMENTASI DAN PENGUJIAN}

\subsection{Implementasi}

Langkah pertama dalam proses implementasi, adalah mencari pengguna yang bersedia untuk menggunakan aplikasi. Pengguna yang dimaksud adalah mahasiswa yang berada disekitar peneliti.

\section{Perangkat Keras}

Perangkat keras yang digunakan dalam membangun sistem ini adalah PC Desktop dengan spesifikasi adalah sebagai berikut:

a. Prosesor : Intel®

Core(TM) i3-370M CPU@ 2.10GHz

b. Sistem Operasi : Windows 8 64-bit

c. RAM

$$
2.00 \mathrm{~GB}
$$

d. Mouse Standar

e. Keyboard Standar

2. Perangkat Lunak

Perangkat lunak yang digunakan dalam mengimplementasikan sistem adalah web browser berbasis desktop, baik chrome, mozilla, opera, dan lainnya.

\section{Implementasi Antarmuka Sistem}

Tampilan aplikasi ketika dijalankan akan ditunjukkan pada Gambar 15 - Gambar 20.
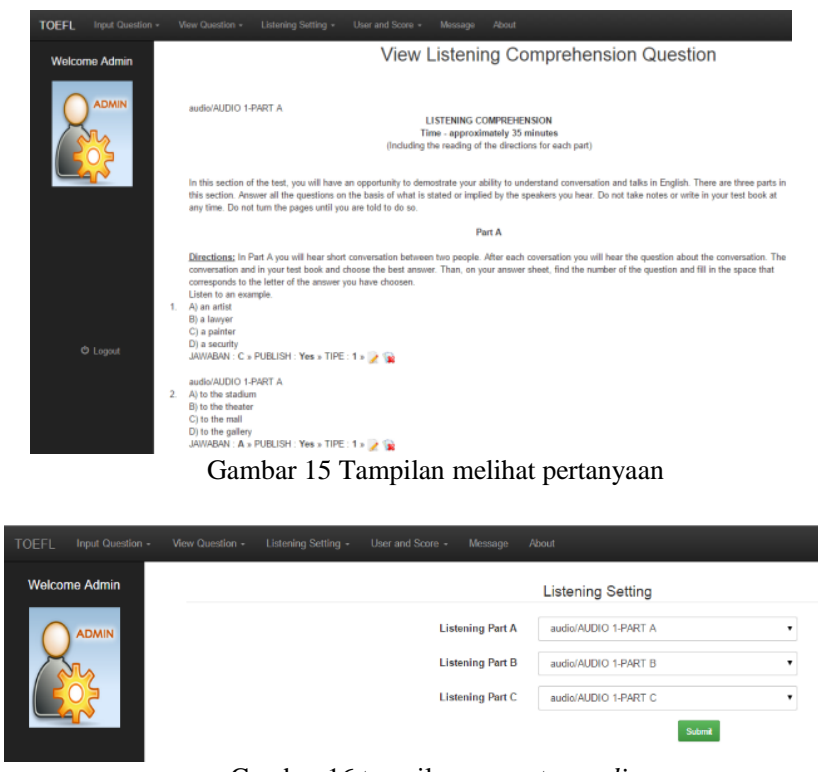

Gambar 16 tampilan mengatur audio

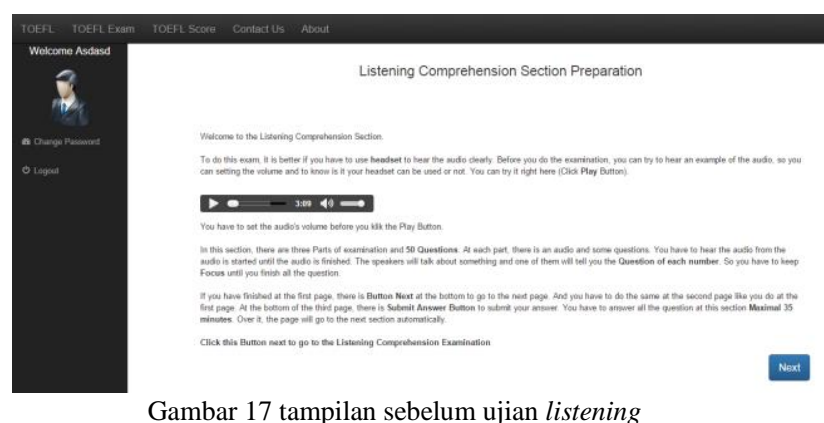

Gambar 17 tampilan sebelum ujian listening 


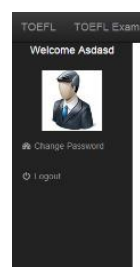

TOEFL Examination
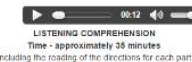

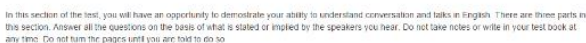
Pan^

Gambar 18 tampilan melakukan ujian listening

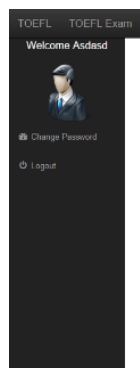

Nila: 21

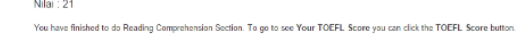

Gambar 19 tampilan setelah mealkukan ujian setiap sesi
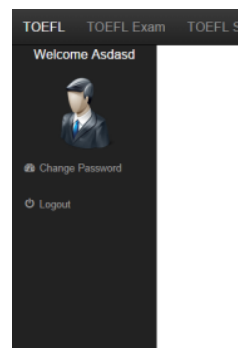

Gambar 20 tampilan skor toefl

Listening Comprehension: 24

Structure and Written Expression: 20

Reading Comprehension: 21

YOUR TOEFL SCORE: 310

\subsection{Pengujian Aplikasi}

Pengujian pada tahap ini bermaksud untuk menguji aplikasi serta memastikan aplikasi dapat berjalan seperti tujuan dan seluruh fungsi dapat digunakan. Pengujian yang dilakukan menggunakan metode black-box. Pengujian black-box merupakan pengujian yang lebih berfokus pada sisi fungsionalitas aplikasi dan tingkat keberhasilan pengujian diukur dari terpenuhinya tujuan dari fungsi yang sudah dibuat.

\section{Pengujian Fungsionalitas}

Pengujian aplikasi ini dibuat berupa tabel pengujian black-box dari fungsi yang ada dalam aplikasi. Tabel 11 menunjukkan hasil pengujian fungsi-fungsi yang terdapat pada aplikasi.

Tabel 11. Pengujian fungsi login dan register

\begin{tabular}{|c|c|c|c|}
\hline $\begin{array}{c}\text { Nama } \\
\text { Pengujian }\end{array}$ & $\begin{array}{c}\text { Bentuk } \\
\text { Pengujian }\end{array}$ & $\begin{array}{l}\text { Hasil Yang } \\
\text { Diharapkan }\end{array}$ & $\begin{array}{c}\text { Hasil } \\
\text { Pengujian }\end{array}$ \\
\hline $\begin{array}{c}\text { Pengujian } \\
\text { pilihan menu }\end{array}$ & $\begin{array}{l}\text { Mengklik tombol } \\
\text { Menu }\end{array}$ & $\begin{array}{l}\text { Menampilkan } \\
\text { pilihan } \\
\text { melakukan } \\
\text { login sebagai } \\
\text { pengguna atau } \\
\text { admin }\end{array}$ & Berhasil \\
\hline $\begin{array}{l}\text { Pengujian } \\
\text { login } \\
\text { pengguna }\end{array}$ & $\begin{array}{l}\text { Mengklik tombol } \\
\text { Login }\end{array}$ & $\begin{array}{l}\text { Menampilkan } \\
\text { tampilan } \\
\text { pilihan form } \\
\text { login }\end{array}$ & Berhasil \\
\hline $\begin{array}{l}\text { Pengujian } \\
\text { pendaftaran } \\
\text { pengguna }\end{array}$ & $\begin{array}{l}\text { Mengklik pilihan } \\
\text { register }\end{array}$ & $\begin{array}{l}\text { Menampilkan } \\
\text { field melakukan } \\
\text { pendaftaran } \\
\text { pengguna }\end{array}$ & Berhasil \\
\hline $\begin{array}{l}\text { Pengujian } \\
\text { field }\end{array}$ & $\begin{array}{l}\text { Mengisi semua } \\
\text { field pendaftaran }\end{array}$ & $\begin{array}{l}\text { Menampilkan } \\
\text { tampilan untuk }\end{array}$ & Berhasil \\
\hline
\end{tabular}

\begin{tabular}{|c|c|c|c|}
\hline $\begin{array}{l}\text { pendaftaran } \\
\text { berhasil }\end{array}$ & $\begin{array}{c}\text { pengguna dengan } \\
\text { benar }\end{array}$ & $\begin{array}{l}\text { melakukan } \\
\text { login }\end{array}$ & \\
\hline $\begin{array}{l}\text { Pengujian } \\
\text { field } \\
\text { pendaftaran } \\
\text { gagal }\end{array}$ & $\begin{array}{c}\text { Mengisi field } \\
\text { pendaftaran } \\
\text { namun masih ada } \\
\text { field yang } \\
\text { kosong }\end{array}$ & $\begin{array}{c}\text { Menampilkan } \\
\text { pemberitahuan } \\
\text { pendaftaran } \\
\text { gagal }\end{array}$ & Berhasil \\
\hline $\begin{array}{c}\text { Pengujian } \\
\text { login sebagai } \\
\text { user }\end{array}$ & $\begin{array}{l}\text { Mengklik pilihan } \\
\text { login }\end{array}$ & $\begin{array}{l}\text { Menampilkan } \\
\text { field login } \\
\text { pengguna }\end{array}$ & Berhasil \\
\hline $\begin{array}{l}\text { Pengujian } \\
\text { field login }\end{array}$ & $\begin{array}{l}\text { Tidak mengisi } \\
\text { field login }\end{array}$ & $\begin{array}{l}\text { Menampilkan } \\
\text { pemberitahuan } \\
\text { field harus diisi }\end{array}$ & Berhasil \\
\hline $\begin{array}{l}\text { Pengujian } \\
\text { login sukses }\end{array}$ & $\begin{array}{l}\text { Mengisi field } \\
\text { username dan } \\
\text { password yang } \\
\text { sudah terdaftar }\end{array}$ & $\begin{array}{c}\text { Masuk ke } \\
\text { halaman } \\
\text { pengguna } \\
\text { dengan level } \\
\text { user } \\
\end{array}$ & Berhasil \\
\hline $\begin{array}{l}\text { Pengujian } \\
\text { login gagal }\end{array}$ & $\begin{array}{l}\text { Mengisi field } \\
\text { username dan } \\
\text { password yang } \\
\text { tidak terdaftar }\end{array}$ & $\begin{array}{l}\text { Menampilkan } \\
\text { pemberitahuan } \\
\text { tidak terdaftar }\end{array}$ & Berhasil \\
\hline $\begin{array}{l}\text { Pengujian } \\
\text { Logout }\end{array}$ & $\begin{array}{l}\text { Mengklik tombol } \\
\text { Logout }\end{array}$ & $\begin{array}{c}\text { Menampilkan } \\
\text { halaman publik } \\
\text { aplikasi }\end{array}$ & Berhasil \\
\hline $\begin{array}{c}\text { Pengujian } \\
\text { login sebagai } \\
\text { admin } \\
\end{array}$ & $\begin{array}{l}\text { Mengklik pilihan } \\
\text { login }\end{array}$ & $\begin{array}{l}\text { Menampilkan } \\
\text { field login } \\
\text { pengguna } \\
\end{array}$ & Berhasil \\
\hline $\begin{array}{l}\text { Pengujian } \\
\text { field login }\end{array}$ & $\begin{array}{l}\text { Tidak mengisi } \\
\text { field login }\end{array}$ & $\begin{array}{l}\text { Menampilkan } \\
\text { pemberitahuan } \\
\text { field harus diisi }\end{array}$ & Berhasil \\
\hline $\begin{array}{l}\text { Pengujian } \\
\text { login sukses }\end{array}$ & $\begin{array}{l}\text { Mengisi field } \\
\text { username dan } \\
\text { password yang } \\
\text { sudah terdaftar }\end{array}$ & $\begin{array}{c}\text { Masuk ke } \\
\text { halaman } \\
\text { pengguna } \\
\text { dengan level } \\
\text { sebagai admin } \\
\end{array}$ & Berhasil \\
\hline $\begin{array}{c}\text { Pengujian } \\
\text { login sebagai } \\
\text { admin gagal }\end{array}$ & $\begin{array}{l}\text { Mengisi field } \\
\text { username dan } \\
\text { password yang } \\
\text { tidak terdaftar }\end{array}$ & $\begin{array}{l}\text { Menampilkan } \\
\text { pemberitahuan } \\
\text { tidak terdaftar }\end{array}$ & Berhasil \\
\hline $\begin{array}{l}\text { Pengujian } \\
\text { Logout }\end{array}$ & $\begin{array}{l}\text { Mengklik tombol } \\
\text { Logout }\end{array}$ & $\begin{array}{l}\text { Menampilkan } \\
\text { halaman publik } \\
\text { aplikasi }\end{array}$ & Berhasil \\
\hline
\end{tabular}

Pada pengujian menu halaman home yang terdiri dari 7 pertanyaan, menu input pertanyaan yang terdiri dari 13 pertanyaan, melihat pertanyaan yang terdiri dari 16 pertanyaan, mengatur audio listening yang terdiri dari 2 pertanyaan, menu mengelola akun dan menampilkan skor yang terdiri dari 5 pertanyaan, menu mengelola pesan yang terdiri dari 2 pertanyaan, menu mengubah kata sandi yang terdiri dari 3 pertanyaan, menu melakukan ujian yang terdiri dari 17 pertanyaan, menu melihat skor TOEFL pengguna yang terdiri dari 1 pertanyaan dengan hasil pengujian menunjukkan bahwa semua item pengujian adalah berhasil.

Berdasarkan hasil pengujian fungsionalitas yang telah dilakukan dapat ditarik kesimpulan bahwa aplikasi sudah berjalan cukup maksimal, tetapi tidak menutup kemungkinan dapat terjadi kesalahan pada suatu saat aplikasi digunakan. Sehingga membutuhkan proses maintenance untuk lebih mengetahui kekurangan dari aplikasi.

\section{Pengujian Pengguna}

Pengujian Beta merupakan pengujian yang dilakukan oleh pengguna akhir perangkat lunak sebagai 
responden dari kuesioner yang berisi pertanyaan mengenai usability dari aplikasi. Jawaban hasil kuesioner kemudian dihitung dengan rumus Skala Likert ${ }^{[22]}$ berikut ini untuk mendapatkan kesimpulan.

Keterangan :

$$
Y=\frac{X}{i} \times 100 \%
$$

$Y=$ Nilai presentase

$i=$ Skor ideal (skor tertinggi Likert dikali dengan jumlah responden)

$X=$ Total skor

Tabel 12 menunjukkan hasil perolehan data dari pertanyaan-pertanyaan kuesioner yang diajukan ke 20 responden.

Tabel 12 Hasil persentase beta

\begin{tabular}{|l|l|c|}
\hline No. & \multicolumn{1}{|c|}{ Pertanyaan } & Persentase \\
\hline 1. & Apakah aplikasi mudah dipelajari? & $83 \%$ \\
\hline 2. & Apakah aplikas mudah digunakan? & $87 \%$ \\
\hline 3. & $\begin{array}{l}\text { Apakah aplikas sesuai dengan } \\
\text { TOEFL PBT? }\end{array}$ & $84 \%$ \\
\hline 4. & Apakah aplikas cukup membantu? & $82 \%$ \\
\hline 5. & Cukup menarik? & $85 \%$ \\
\hline 6. & $\begin{array}{l}\text { Apakah mudah mengakses ke menu } \\
\text { aplikasi? }\end{array}$ & $87 \%$ \\
\hline 7. & $\begin{array}{l}\text { Apakah kebutuhan pengguna telah } \\
\text { terpenuhi? }\end{array}$ & $86 \%$ \\
\hline 8. & $\begin{array}{l}\text { Apakah menu dan tampilan mudah } \\
\text { diingat? }\end{array}$ & $82 \%$ \\
\hline 9. & Apakah setiap menu berjalan baik? & $89 \%$ \\
\hline
\end{tabular}

Tabel 14 menunjukkan nilai-nilai hasil pengujian usability terhadap masing-masing pertanyaan memiliki persentase terendah $82 \%$, dimana bila hasil persentase berada diatas $80 \%$ berarti berada pada daerah kuat sangat kuat. Hal ini dapat diartikan bahwa aplikasi TOEFL yang diuji sudah memberikan nilai yang baik terhadap penerimaan dari sisi pengguna dalam 5 aspek usability.

\section{Pengujian Reliability}

Berdasarkan uji skenario stress testing website dengan tool WAPT 8.5 trial version, diketahui hasil pengujian seperti ditunjukkan pada Tabel 13.

Tabel 13 Hasil pengujian reliability

\begin{tabular}{|c|l|c|c|}
\hline No & Kategori & Sukses & Gagal \\
\hline 1 & Sessions & 155 & 6 \\
\hline 2 & Pages & 126 & 0 \\
\hline 3 & Hits & 411 & 3 \\
\hline \multicolumn{2}{r|}{ Total } & 692 & 9 \\
\hline
\end{tabular}

Berdasarkan hasil pengujian reliabitas menggunakan WAPT 8.5 trial version seperti ditunjukkan pada Tabel 15 maka dapat dihitung nilai error rate dan Reliability sebagai berikut.

$$
\mathrm{r}=\frac{f}{n}=\frac{9}{692}=0.013
$$

Keterangan:

$$
\begin{aligned}
& f=\text { total failure yaitu } 9 \\
& n=\text { total test case yaitu } 692 \\
& r=\text { error rate yaitu } 0.013
\end{aligned}
$$

$$
\mathrm{R}=1-\mathrm{r}=1-0.013=0.987
$$

Keterangan:

$$
\begin{aligned}
& r=\text { error rate yaitu } 0.013 \\
& R=\text { reliability yaitu } 0.987
\end{aligned}
$$

Dari perhitungan diatas dapat diketahui bahwa nilai error rate (r) yaitu 0.013 dan nilai reliability (R) yaitu 0.987. Maka setelah nilai reliability dicocokkan dengan standar Telcordia, dapat disimpulkan bahwa perangkat ini dapat diterima dan memenuhi kriteria standar reability yang ditetapkan oleh Telcordia.

\subsection{Kesimpulan}

\section{Penutup}

Berdasarkan hasil analisis dan pengujian pada aplikasi TOEFL, maka dapat diambil kesimpulan sebagai berikut:

1. Aplikasi ujian TOEFL berbasis web yang dibuat sudah dapat digunakan untuk menguji kemampuan bahasa Inggris dengan hasil kahir berupa skor TOEFL.

2. Berdasarkan hasil pengujian black box, aplikasi sudah berjalan dengan baik dengan semua tombol dapat digunakan dan menampilkan tanggapan sesuai dengan yang seharusnya.

3. Berdasarkan hasil pengujian beta, hasil kuesioner dari pengujian aplikasi dapat disimpulkan bahwa perangkat lunak yang dibangun mudah dipelajari, mudah digunakan, fungsi yang terdapat didalam aplikasi sesuai dengan ujian TOEFL PBT biasanya, dapat digunakan untuk menilai kemampuan diri, antarmuka yang digunakan menarik, mudah untuk mengakses ke menu aplikasi, kebutuhan pengguna sudah sesuai dengan menu dan fasilitas yang telah disediakan, menu dan tampilan mudah untuk diingat, dan setiap menu dalam aplikasi ini dapat berjalan dengan baik dimana berdasarkan hasil ratarata pengujian aplikasi memiliki persentasi $\geq$ dari $80 \%$, yang berarti hasil pengujian dari setiap pertanyaan berada dalam persentase hasil kuat sampai dengan sangat kuat. Hal ini menunjukkan bahwa aplikasi memberikan nilai baik terhadap penerimaan dari sisi pengguna dalam 5 aspek usability.

4. Berdasarkan hasil pengujian reliability, didapat bahwa nilai error rate (r) yaitu 0.013 dan nilai reliability ( $\mathrm{R})$ yaitu 0.987 , dimana berdasarkan standar Telcordia dapat disimpulkan bahwa perangkat ini memenuhi kriteria standar reability. 


\subsection{Saran}

Saran yang diberikan dalam upaya pengembangan aplikasi yang lebih baik dikemudian hari.

1. Dapat dikembangkan aplikasi Ujian TOEFL sebagai Media Pelatihan Bahasa Inggris Berbasis Web dengan menggunakan bahasa pemrograman selain PHP dan mesin basis data selain MySQL agar dapat dibandingkan kinerjanya.

2. Perlu dilakukan penelitian lanjutan untuk mengembangkan tes kemajuan Bahasa Inggris yang lebih bervariasi, sesuai dengan kebutuhan yang ada di pasar, seperti TOEP, IELTS, TOEIC, dan sebagainya sehingga pengguna dapat menilai kemampuan Bahasa Inggris sesuai dengan kebutuhannya.

3. Aplikasi Ujian TOEFL sebagai Media Pelatihan Bahasa Inggris Berbasis Web ini dapat dikembangkan lebih lanjut dengan membangun aplikasi yang berbeda platform.

\section{DAFTAR PUSTAKA}

[1] Parwanto, T., "Perancangan Aplikasi Simulasi TOEFL (Test of English as Foreign Language)," no.

[2] 5-10-2012, p. 3, 2011.

Triyadi, E., "Perancangan Aplikasi Tes TOEFL Mobile Menggunakan Teknologi J2me Pada Ponsel Berbasis Java Sebagai Media Pembelajaran,” 2011.

[3] Pratiwi,A., Mayasari, A. R., dan Rahmasari, G., 100\% Best Guide to TOEFL Up to 600, Jakarta: Laskar Aksara, 2011.

[4] Hinkel, E., TOEFL Test Strategies, Jakarta: Binarupa Aksara, 2005.

[5] Purmaning, E. R., Ayuningtyas, A. K., Hudha, Nurul, Tip \& Trik Melejitkan Skor TOEFL, Jakarta: Cmedia, 2012.

[6] Fauzy, E. K., Yudiashari F., dan S, Lidya Cristina, Break Down! Soal-Soal TOEFL, Bandung: RuangKata, 2013.

[7] Supriyanto, A., Pengantar Teknologi Informasi, Jakarta: Salemba Infotek, 2005.

[8] Bakri, Z., dan Hidayaningsih, P. S., "Internet : Pengiriman file," vol. VII, p. 24, 1997.

[9] Noviyanto, F., dan Ashari, A., "Penerapan Teknologi Ria untuk Membangun Aplikasi Web dengan Pengaksesan Real Time (Studi Kasus: Pemesanan Handphone Online)," vol. V, no. 1, p. 486, 2013.

[10] Noviyanto, F., dan Wahyu, D. D., "Rich Internet Aplication (RIA) untuk Aplikasi Sistem Informasi Klinik Kesehatan," vol. III, no. 2, pp. 341-349, 2015.

[11] Dharma, F., "Pengaruh Structural Assurance dan Perceived Reputation Terhadap Trust Pengguna Internet di Sistem E-commerce," p. 6, 2006.

[12] F, M. M., PHP Tutorial Book for Beginner, Yogyakarta: Notebook, 2014.

[13] L. Dwiartara, "Menyelam dan Menaklukan Samudra PHP," Ilmuwebsite. com, p. 3, 2012. [15]
Dananjaya, J., Folklor Indonesia Ilmu, Gosip, Dongeng, dan lain lain. Jakarta: Grafitipers, 1984.

[14] Raharjo, B., Heryanto, I., dan K., E. R., Modul Pemrograman WEB (HTML, PHP, \& MySQL), Bandung: Modula, 2012.

[15] Kadir, A., Tuntutan Praktis: Belajar Basisdata Menggunakan MySQL, Yogyakarta: Andi, 2008.

[16] Kadir, A., Dasar Pemrograman Web Dinamis Menggunakan PHP, Yogyakarta: Andi, 2002.

[17] Solichin, A., "MySQL 5: Dari Pemula Hingga Mahir," p. 6, 2010.

[18] Elisabeth, R., dan Eric, F., "Head First HTML and CSS 2nd Edition," p. 28, 2012.

[19] Ariona, R., "Belajar HTML dan CSS - Tutorial Fundamental dalam Mempelajari HTML dan CSS," p. 58, 2013.

[20] academia, "academia," [Online]. Available: https://www.academia.edu/7585995/BAB_I_Model_ Waterfall. [Accessed 21 April 2015].

[21] Sommerville, I., Software Engineering, Eighth Edition. Addison-Wesley, 2007.

22] Sugiyono, Metode Penelitian Kuantitatif Kualitatif dan $R \& D$. Bandung, Indonesia: Alfabeta, 2009.

[23] Pressman, Roger S., Software Engineering: A Practitioner's Approach, Seventh Edition. New York: McGraw-Hill Companies, Inc, 2010.

[24] Tian, J., "Evaluating Web Software Reliability Based on Workload and Failure Data Extracted From Server Logs, ” p.754, 2004.

[25] Asthana, A., dan Olivieri, J., "Quantifying Software Reliability and Readiness," 2009.

[26] Sudarmono, E., THE KING TOEFL Tips \& Trik plus Bank Soal. Jakarta Selatan: Wahyumedia, 2013. 